\title{
切欠平板引張試験片の弾塑性挙動と 破壊特性に関寸る一考察
}

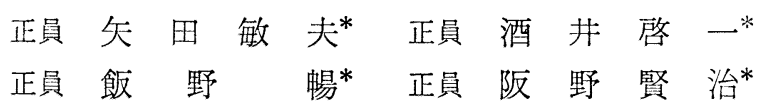

A Study on Elasto-plastic Behavior and Fracture Characteristics of Notched Plate Tensile Specimen

$\begin{array}{cc}\text { by Toshio Yada, Member } & \text { Keiichi Sakai, Member } \\ \text { Nobu Iino, Member } & \text { Kenji Sakano, Member }\end{array}$

Summary

Elasto-plastic behavior for both center notched and side notched plate specimens were studied as a first step toward prediction of fracture.

Elasto-plastic analysis by finite element method and brittle coating were used to approach the problem. At each stress level, brittle coating cracks formed at high strain range showing contours of equal strain was in good agreement with the predicted shape using the finite element method.

Fracture test results on both center notched and side notched specimens were compared. And they were discussed on the basis of elasto-plastic analysis.

From examination of the properties of matrices, it was made clear that a computed result for a given condition of a specimen can directly be applied to obtain solution in different state if

i) geometric similarity exists in specimens

ii) the Young's modulus and strain hardening coefficient are varied while the ratio between the two is kept constant.

iii) yield stress is varied in specimens.

\section{1 緒}

言

脆性破壊の発生を規定する物理量として，K值， COD 值あるいは $\rho^{+}$值などが提案され，破壊鞋性の評価に 用いられている。これらの規準を適宜に選べば，切久をモデル化して行なら弾性論的な解析手法により，実験室

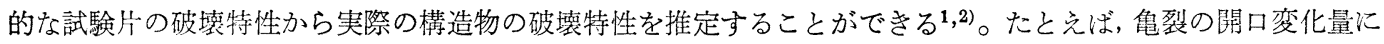
注目した破锌規準である COD 值は直接計測が可能なことなど有用な破壊規準と考兄られ, 残留応力が付加され る場合あるいは応力履歴を受ける場合の勒性評価にも適用が試みられている3)。また最近では COD 值を破壊規 準にとり，試験を標準化することについても検討が行なわれている゙)。

しかしながら, 試験片の形状が異なる場合の破壊特性，あるいは板厚の異なる場合の塑性拘束の影響なぞ明確 にされていない問題も少なくなく, 研究が進められている5)。また破壊発生に及汸す伈力の種類の影響, 構造的 な部材拘束の影響なども明らかにすべき問題である。

脆性破壊の発生現象を定量的に解析することが困難である最大の理由は, 脆性破壊の発生起点の近傍に生じる 応力・ひずみ状態が複雑なことである。

* 石川島播磨重工業(株)技術研究所 
しかし近年のコンピュータの発達に伴い, 破䏅力学の分野にも有限要素法（FEM）による計算技術が導入さ

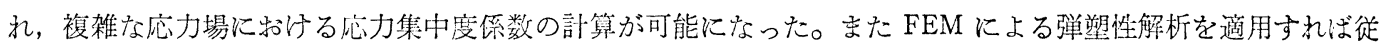
来亀裂モデルについて近似的に理論解析を行なっていた切欠の弾塑性挙動を直接計算で求めることができ, 破壞 発生の規準の検討を進妨る壳できわ好有効であると考兄られる。

このような観点から著者らはエレメントを逐次降伏させる FEM 弾塑性解析プログラムを用いて，切欠の変形 挙動拉よび切欠先端部の応力ーひずみ分布を求めた。

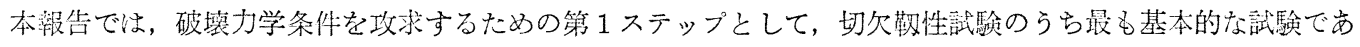
る切欠引張試駼をとりあげ, センタノッキ試駼片とサイドノッチ試騟片について, 平面応力就よび平面ひずみ状

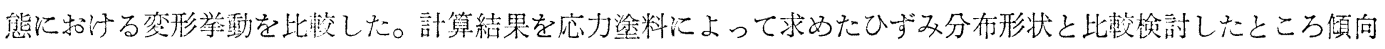
的には良い一致をみ文。

またセンタノッチ試験片とサイドノッチ試験片による引張破壊試験を行ない, 試験結果を弾塑性解析によって 得られた知見をるとに考察した。

破壊力学条件を検討するためには多くのケースについて解析を行なら必要があるが，FEM で得られるのは数

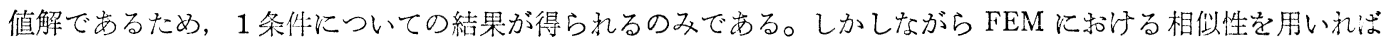
他の計算条件の場合にも適用できる場合があり，計算結果の活用法について検討した。

\section{2 切欠材の引張変形挙動}

センタノッチ $(\mathrm{CN})$ 拉よびサイドノッチ (SN) の試験片を平面ひずみ拉よび平面応力の条件のもとに FEMに よる弾塑性解析を行ない，応力ひずみ等にどのような差がみられるかを調べた。また，FEM の解析に用いた 試駼片と同じ形状の試験片を軟鋼板で製作し，その表面に応力塗料を塗布しひずみ分布の状態を調べた。これら の結果について報告する。

\subsection{FEM による解析}

\subsection{1 解析の条件}

$\mathrm{CN}$ と $\mathrm{SN}$, 平面応力と平面ひずみの各条件 について同じ寸法, 要素分割で弾塑性解析を行 なった。試験片寸法㧍よび要素分割を図1 亿示 す。試験片は対称性を考兄 $1 / 4$ の部分を示して ある。切欠は簡単のためスリットとした。材料 としてはHT 80 を考光降伏応力 $\left(\sigma_{Y}\right)$ に $75 \mathrm{~kg} /$ $\mathrm{mm}^{2}$, ヤング率 $(E)$ に $21,000 \mathrm{~kg} / \mathrm{mm}^{2}$, 加工 硬化率 $(H)$ に $100 \mathrm{~kg} / \mathrm{mm}^{2}$, ポアッソン比 ( に0.3を用いた。弹塑性の解析法憎分法であ
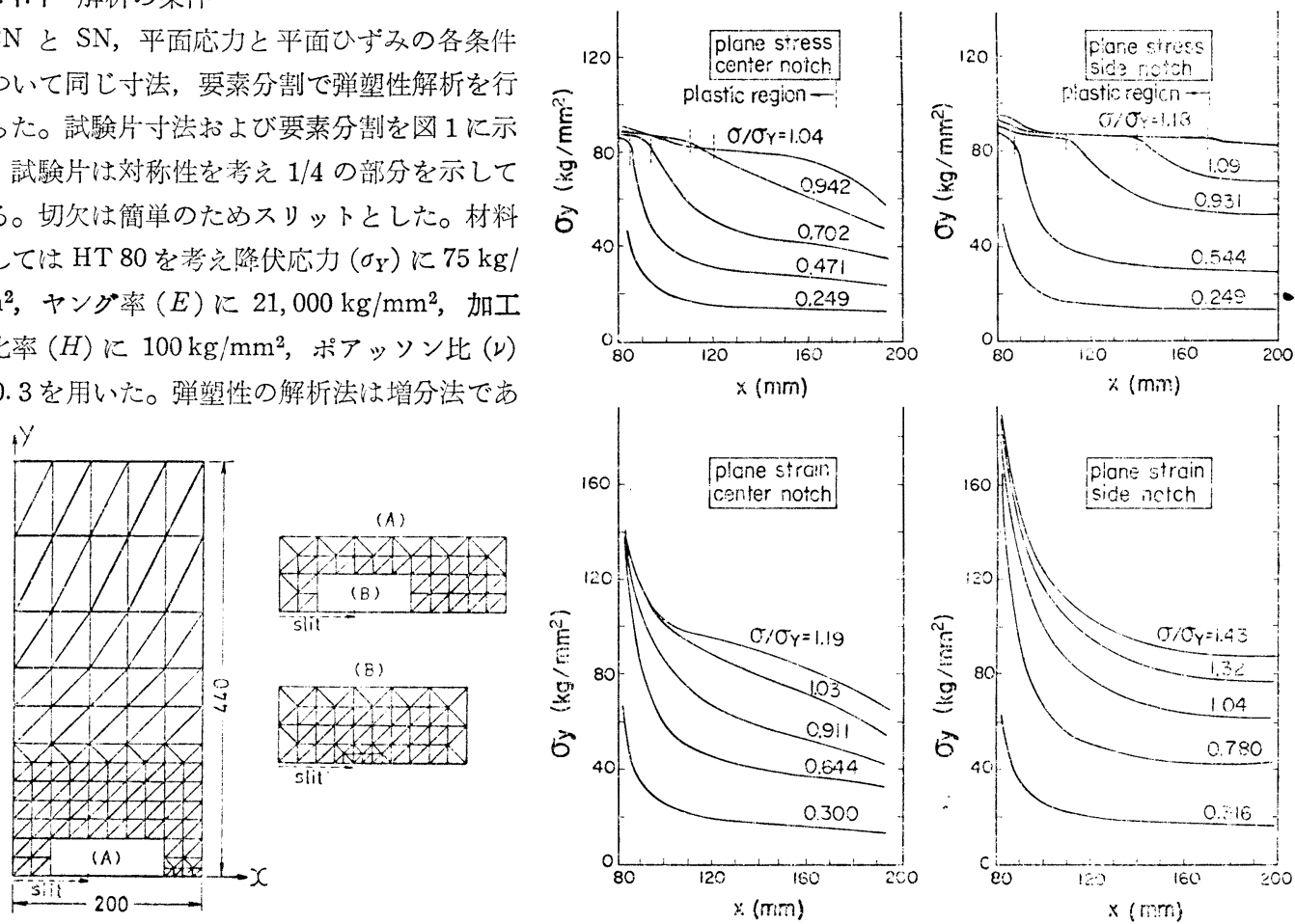

(E)

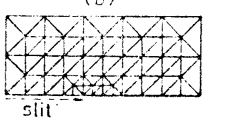

図 1 解析の対象とした試験片寸法礼よび 要菜分割
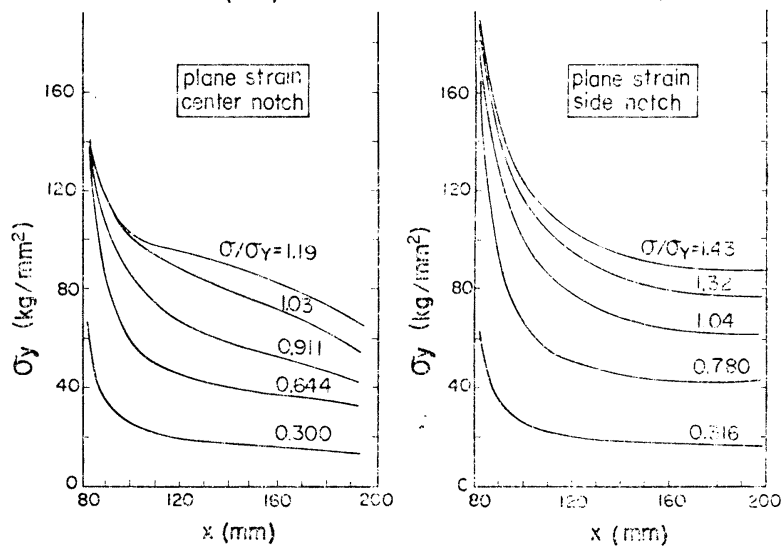

図 2 切欠線上の軸方向灾力 $\sigma_{y}$ の分布 
り，增分量は弾性域にある要素が 1 個だけ降伏点に達するように自動的に洪まるようにし，降伏条作としては Mises の降伏条件を用いた。各增分間は微小変形で晾るとし, 前段階の状態について平衡を考劣変位, ひずみ, 合力の增分を求めた。

\subsection{2 切欠線上の応力分布}

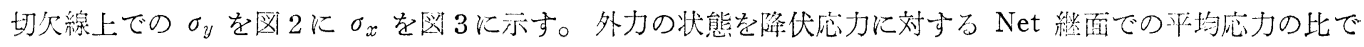
示してちる。ただし $\sigma_{y}$ は荷重䩜方向， $\sigma_{x}$ は切欠線方向の垂直㐫力を表わす。

の についてみると，切欠先端还傍の忘力值は平面ひずみの場合が平面応力の場合に比べて相当高いことがわ

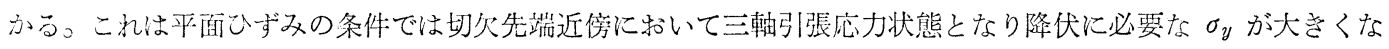
るたかである。平面态力の場合には切火先端近くでわずかに上昇の傾向がみられるが，佐藤らの報告6にによれば 平面灾力状態であっても要素分割を組かくすれば切欠先端のすぐ近くの要素は加工硬化により降伏応力の 2 倍近

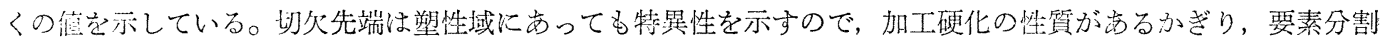

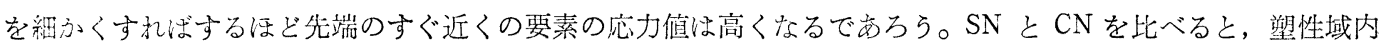
で心SNがわずが高い值を示しているが，これは後に述べるように $\sigma_{x}$ の影響によるものである。
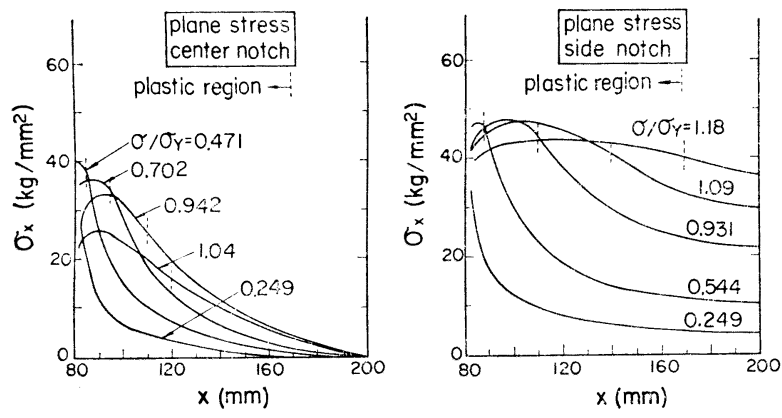

$\sigma_{x}$ についてみると, 切欠近傍ではやはり 平面ひずみの場合が平面応力の場合に比べて 高いことがわかる。 $\sigma_{x}$ の特徴として切欠近 傍の值は荷重の小さい範团では荷重の増加に より大きくなるが，ある荷重を境に逆に低下 する傾向にある。この低下により $\sigma_{x}$ は切欠 先端からある距離の所でピークを示し，ピー クを示す位置は外力の增大により切欠先端か ら離れていく傾向に㐫る。また $\sigma_{x}$ の低下は 平面ひずみに比べて平面応力の場合に早くか
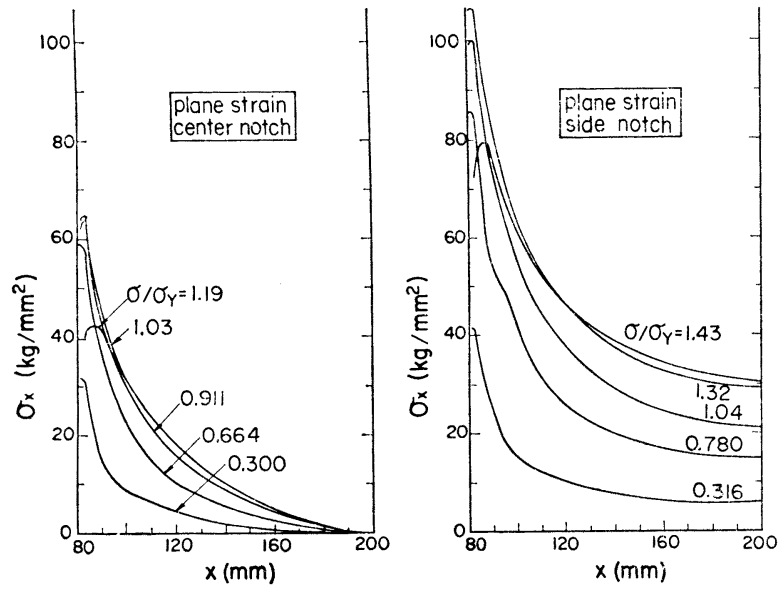

図 3 切欠線上の横方向応力 $\sigma_{x}$ の分布

麦 $1 \mathrm{FEM}$ により得られた全面降伏時の応力

\begin{tabular}{l|c|c|c|c}
\hline & \multicolumn{2}{|c|}{ plane stress } & \multicolumn{2}{|c}{ plane strain } \\
& $\mathrm{CN}$ & $\mathrm{SN}$ & $\mathrm{CN}$ & $\mathrm{SN}$ \\
\hline$\sigma_{G Y}\left(\mathrm{~kg} / \mathrm{mm}^{2}\right)$ & 77.2 & 85.0 & 88.7 & 99.3 \\
$\sigma_{G Y} / \sigma_{Y}$ & 1.03 & 1.13 & 1.18 & 1.32 \\
\hline
\end{tabular}

$\sigma_{G Y}:$ General yield stress at net section
ら生じるようである。これは，平面応力の場 合には塑情域は切欠線上前方に拡がるが，平 面ひずみの場合には，ほとんぞ前方へ扗がら ないことに関係しているのであろう。平面応 力の場合には図中に切欠線上の塑性域の長さ を示したが, 平面ひずみでは全面降伏時でも 切欠線上の塑性域は $5 \sim 7 \mathrm{~mm}$ 程度と小さか ったので省略した。

CN と SN を比べると，全体に SN の暢合 に高い値を示して扣り, 荷重の增加に伴う $\sigma_{x}$ の低下の傾向は $\mathrm{CN}$ の方が大きいようで ある。

このよらに試験片の状態により, 主応力 值, 応力比が巽なるので, 試験片が全面降伏 となる荷重に差が生じる。これを示したのが, 表1で ある。平面応力の Center notch では注汴一軸での降 伏応力に等しい。

$\mathrm{CN}$ と $\mathrm{SN}$ の差は $\sigma_{x}$ の差にもよるものであり, $\mathrm{CN}$ に比べSN の $\sigma_{x}$ が大きいのは試験片端部の弾性部分 が板幅方向の収縮を防げるためである。したがって $2 C / W$ が変化すれば，SN の全面降伏応力は変化する ことが予想される。このことを確めたのが図 4 に示す

実駼結果である7)。板厚 $1.6 \mathrm{~mm}$ の軟鋼板を用い有効断面を一定にし切久深さを变化させた試験片について引張 
試験を行ない降伏応力を求めたものである。板幅方向の ひずみ $\varepsilon_{x}=0$ であるとすれば，平面応力状態 $\left(\sigma_{z}=0\right)$ で は $\sigma_{y}=2 \sigma_{x}$ （但し $\nu=0.5 ）$ となり, Mises の降伏条件 汇従光ば $\sigma_{y} / \sigma_{Y}=2 / \sqrt{3} \doteqdot 1.15$ となる。この実験では $W / d=3$ 程度でほぼ 1.15 倍となっていることがわかる。 また FEM の解析により得られた結果もプロットしてあ るが実験値と良い一致を示している。

平面ひずみで $\mathrm{CN}$ の場合には， $\sigma_{x} \doteqdot 0$ 上り平面応力の 場合と比べて 1.15 倍になっている。平面ひずみで SN は $\sigma_{x}>0, \sigma_{z}>0$ であるため, 降伏応力が大きく上昇し ている。

\section{1 .3 ひずみ分布}

ひずみ状態については，全面降伏直後の $\varepsilon_{y}$ 等ひずみ 領域を図 5 に示す。SN の場合には，ひずみ量が小さく変形しにくい状態にあることがわかる。なお，SN の場 合降伏が進行する方がわかるように荷重が増加した状態での 0.5 ひずみ域も示した。ここでは $\varepsilon_{y}$ について示 したが，相当応力や相当ひずみの分布形状すなわち塑性域の形状もほぼ同様な傾向にある。

平面ひずみと平面応力とを比べると，平面応力の場合には切欠先方にもひずみの大きい領域は広がっているが 平面ひずみでは切欠先方へ注とんど広がらないことがわかる。
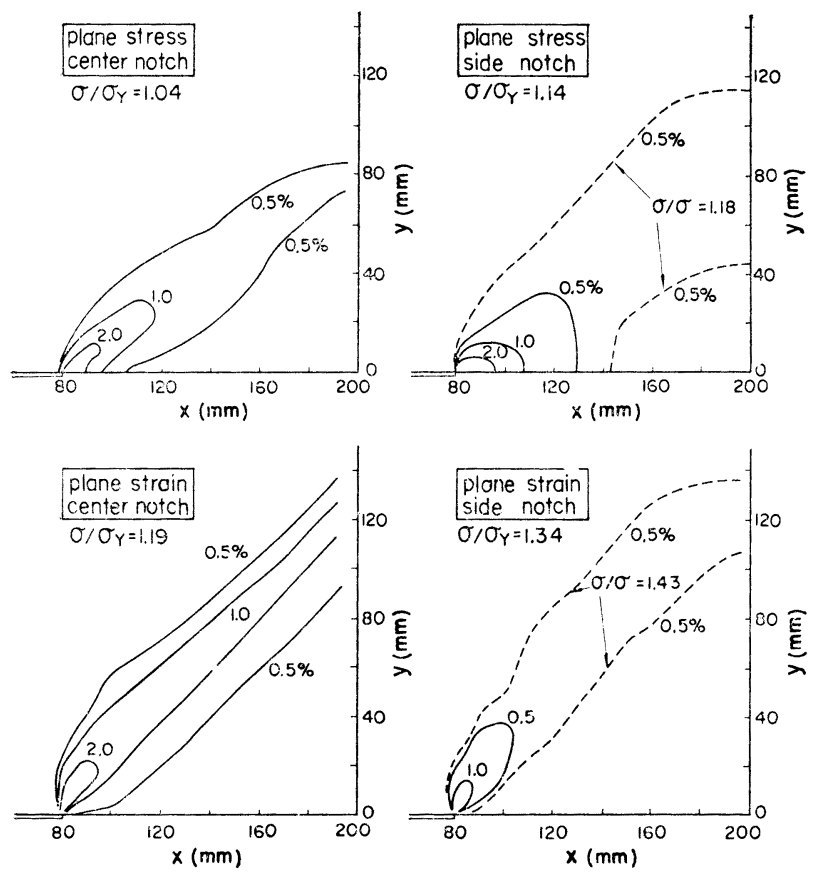

図 5 全面降伏直後の等ひずみ領域 $\varepsilon_{y}$

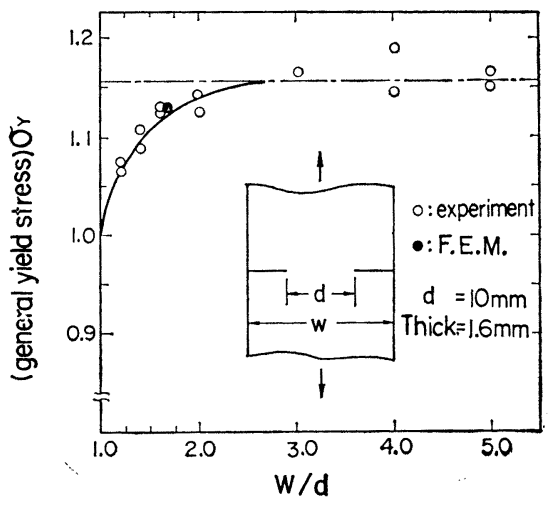

図 4 全面降伏強度に拈よほす切欠深さの影響

\section{1. $4 \mathrm{COD}$}

応力と COD の関係を示したのが困6で劣 る。COD としては切欠先端より $5 \mathrm{~mm}$ の位 置を示し，同位置でのDM モデル汇よる值す 示した。各条件により全面降伏応力が異なる ので，応力-COD 関係もその影響を受计，

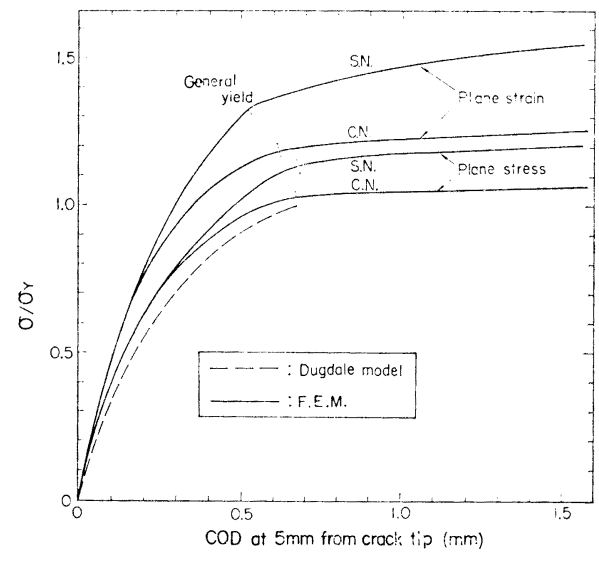

図 6 応力と切欠先端から $5 \mathrm{~mm}$ の位置の COD の関係

同じ応力状態で降伏応力が高くなる条件の COD が小さい值をとっている。したがって，拘束により降㐲闷力 が変化する試験片や欠陥材の COD を DM モデルを用いて計算により求める場合には，降伏応力の变化を考皇た 適当な補正が必要で市る。

\section{2 応力塗料による変形の観察}

2.2.1 供試材拉よび試験片形状

供試材の機械的性質を表 2 亿示す。板厚 $20 \mathrm{~mm}$ の鋼板を表面研磨して $19 \mathrm{~mm}$ 厚とした。 
表 2 供試材の機械的性賀

\begin{tabular}{c|c|c|c}
\hline $\begin{array}{c}\text { 降伏强さ } \\
\left(\mathrm{kg} / \mathrm{mm}^{2}\right)\end{array}$ & $\begin{array}{c}\text { 引張强ざ } \\
\left(\mathrm{kg} / \mathrm{mm}^{2}\right)\end{array}$ & 伸び率（\%) & 校り（\%) \\
\hline 23.8 & 44.4 & 24.0 & 45.3 \\
\hline
\end{tabular}

G. L. $=200 \mathrm{~mm}$
試験片は平板引張試験片および $\mathrm{SN}, \mathrm{CN}$ のディー プノッチ試験片(幅 : $W=400 \mathrm{~mm}$, 切欠長 : $2 C=160$ $\mathrm{mm}$, 切欠の先端 $2 \mathrm{~mm}$ は $0.2 \mathrm{~mm}$ 幅, 他は $2 \mathrm{~mm}$ 幅）の3種類を製作した。

2.2 .2 実験方法

試験片の表面に応力塗料（TL-500-75 B）を塗布し，

約 24 時間放眉した後引張試験を実施した。平板引張試験片では，材料の機械的性質を調べるとともに，応力塗 料の状態とひずみ量との関係を調べた。ディープノッキ試験片では，ひび割れ，およびはくり域の状熊について 観測した。

\section{2 .3 実験結果蛒よび考察}

平板試験片の引張試験により，応力塗料にひび割れができるのは，ひずみ量が $750 \mu$ 程度であり，塗料がはく りを始めるのはひずみ量が 20000〜25000 $\mu$ であった。

ディープノッチ試験片のとり付けの不整のため試験片に曲げ応力が生じ，表裏で塗料にひび割れに差を生じた ため，ひび割れの状態についての報告は割愛し，曲げの影響がほとんど無くなる全面降伏以後の㙦料のはくり状 態について報告する。

塗料のはくりが琶められるのは，全面降伏付近からであり，はくり域は双葉のような形状である。これは図 5 に示した平面ひずみ状態の場合の等ひずみ領域の形状に良く似ている。このような状態はクラックが進展し始め る最高荷重近くまでつづき，荷重の增加ととるにはくり域は切欠線の延長線に近づいていく。

$\mathrm{CN}$ と SN では初期のはくり域の形状は似ているが，大きさは CN の方が大きい。最高荷重は CNでは 145 ton, SN では 155 ton であったが，そのときのはくり域も CN の方が大きい。最高荷重近くではくり域は急速に 払大するがその形状は $\mathrm{CN}$ と $\mathrm{SN}$ とでかなり相違がある。すなわち CNでは，はくり域は切欠線上前方へす広が

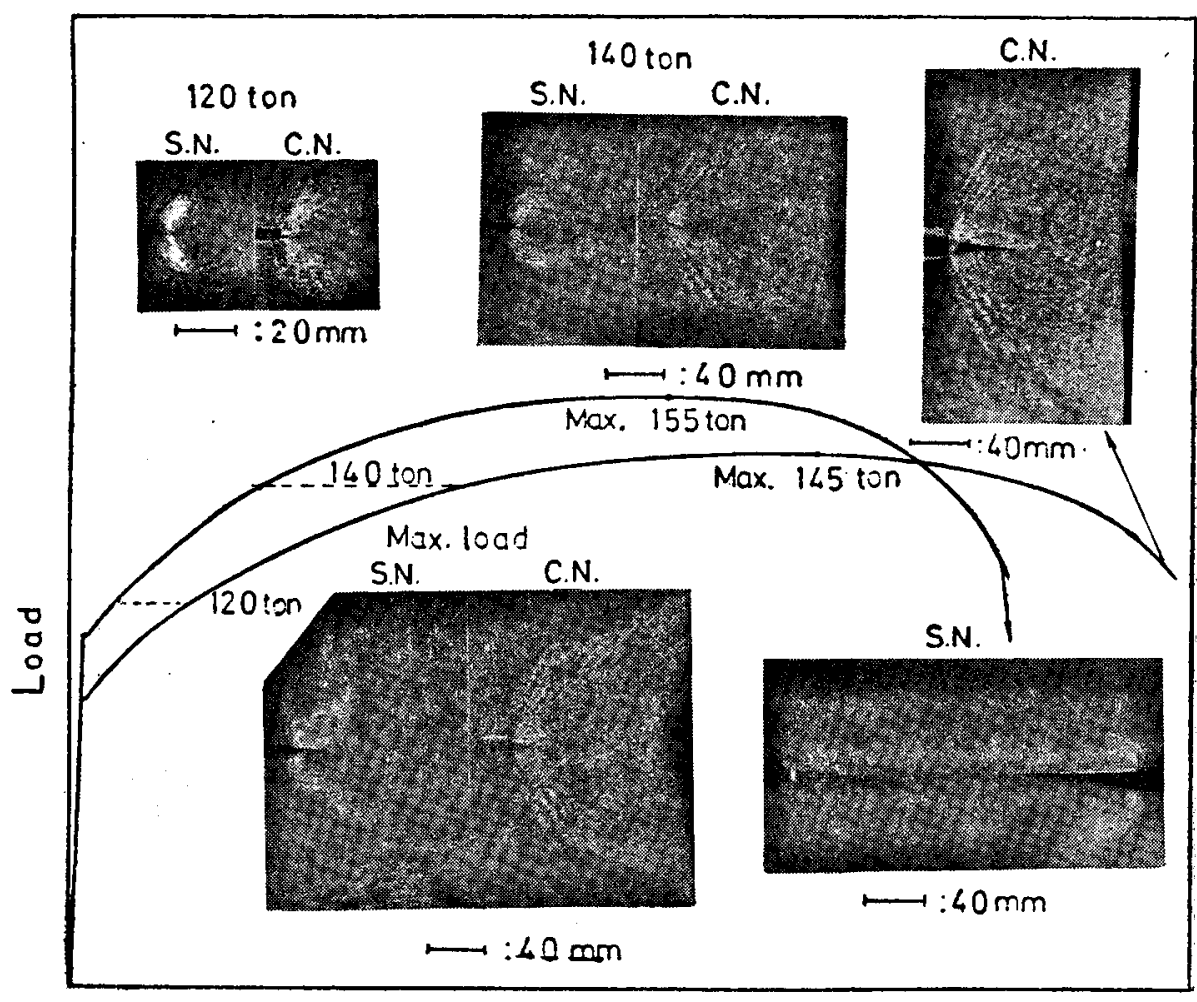

Elongation

因 7 荷重一伸び曲線の模式図と応力粱料のはくり状態 
り，その形状は FEM の解析で平面応力状態について得られた等ひずみ領域の形状と似ている。一す SN で怘切 欠線の延長方向には，はくりは広がらず，切欠先端から $45^{\circ}$ の力向にすべりが起りこれに沿って塗料がはくりし ているのが認められる。しかしはくり量は CN に比べるとはるが小さい。

さらに負荷すれば，龟裂は徐々に進展していくが，これにつれてCN ではなだはくりしていない隹裂先端の残 部に执いてもはくりし，広い領域にわたって一様なはくりが観察される。一方 SN で初期の㓛火先端位置から $45^{\circ}$ 方向のみにはくりが梁められる。はくりが明瞭になるのは主に最高荷重直後の变形によるもので市る。ざ

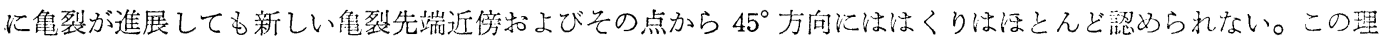
由は主として以下に述べるようなすべり方向の相違によるるのと考光られる。

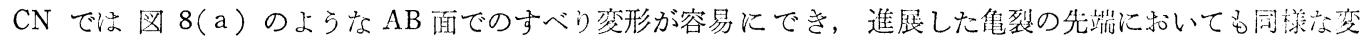

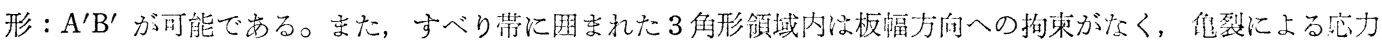
集中を除けば平滑材を引張った場合の応力ーひずる状態に近くひずみは全領域にわたって浮注一椂になる。この ため全体的にはくりを生じることになる。

SN についても Fig.8（b ）に示すような亀裂先端部から $45^{\circ}$ 万向へのすべり変形は最高荷重前後に生じるが， すべり線が試験板中央でぶつかり，この変形は大きくなり得ない。さらに龟裂が進展した状態では $45^{\circ}$ 方向のす ベりによるはくりは認められず，変形は板厚方向のすべりが主となっているようである。これは，亀裂が長くな り板厚力向の変形を拘束する部分が大きくなること，亀裂先端がかなり塑性変形した領域に入り，平面応力条件

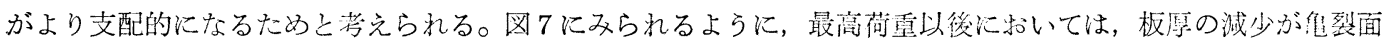
汇平行に生じているが叙料のはくりは少ない。

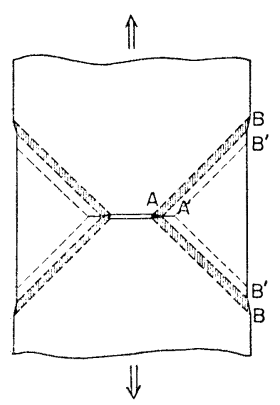

(a)

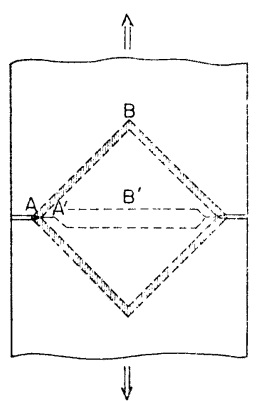

(b)

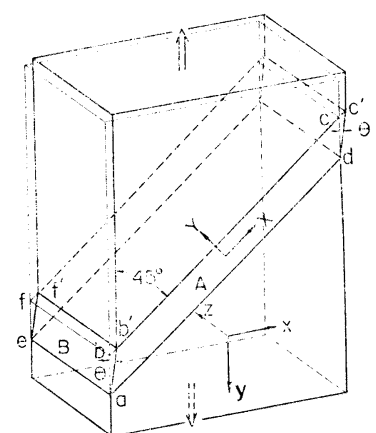

(a)

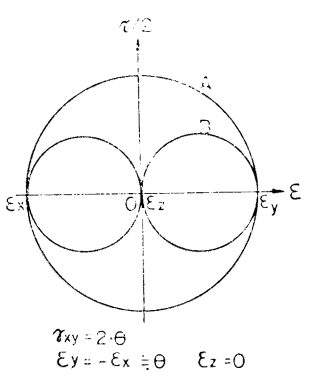

(b)

図 $8 \mathrm{SN}$ および $\mathrm{CN}$ 試獎片のすべり変形状態

图 9 すがり带内のひず及状俧

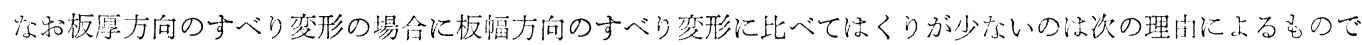
交らら。

图 9 のようなすべり变形を考光れば,

$$
\varepsilon_{X}=\varepsilon_{Y}=\varepsilon_{Z}=0, \quad \gamma_{X Y}=2 \theta
$$

となる。したがって

$$
\varepsilon_{x}=-\varepsilon_{y}=-\theta, \quad \varepsilon_{z}=0, \quad \gamma_{x y}=0
$$

となる。

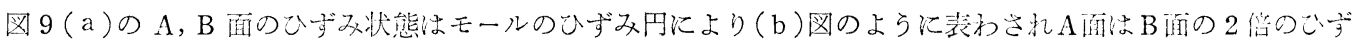

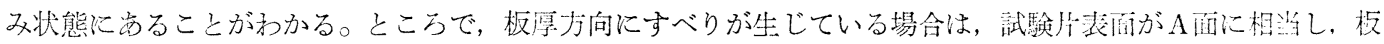

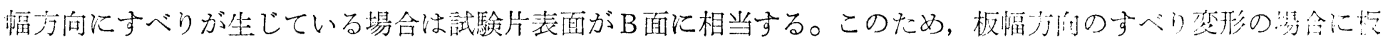
厚方向のすべり变形に比べてはくりが蕃しく六ると考えられる。

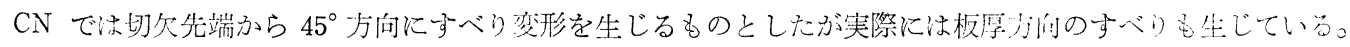

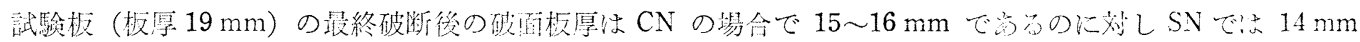

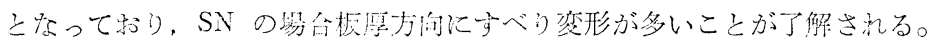

\section{3 センタノッチおよびサイドノッチ試験片の破壊詿験}

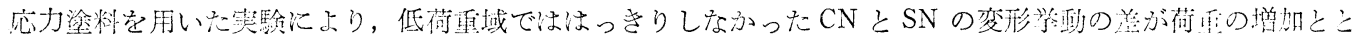


衣 3 供試材の化学組成および機珹的性質

\begin{tabular}{c|c|c|c|c|c|c|c|c|c|c|c}
\hline \multicolumn{10}{c}{ 化 学 組 成 $(\%)$} \\
\hline $\mathrm{C}$ & $\mathrm{Si}$ & $\mathrm{Mn}$ & $\mathrm{P}$ & $\mathrm{S}$ & $\mathrm{Ni}$ & $\mathrm{Cr}$ & $\mathrm{Mo}$ & $\mathrm{Cu}$ & $\mathrm{V}$ & $\mathrm{Ti}$ \\
\hline 0.13 & 0.26 & 0.87 & 0.009 & 0.005 & 0.12 & 0.73 & 0.42 & 0.27 & 0.035 & - \\
\hline
\end{tabular}

\begin{tabular}{c|c|c|c|c}
\hline 降伏強さ $\left(\mathrm{kg} / \mathrm{mm}^{2}\right)$ & 引張強さ $\left(\mathrm{kg} / \mathrm{mm}^{2}\right)$ & 作び率 $(\%)$ & 絞り $(\%)$ & 板厚 $(\mathrm{mm})$ \\
\hline 77.1 & 83.5 & 20.0 & 70.0 & 27 \\
\hline
\end{tabular}

JIS 4 号
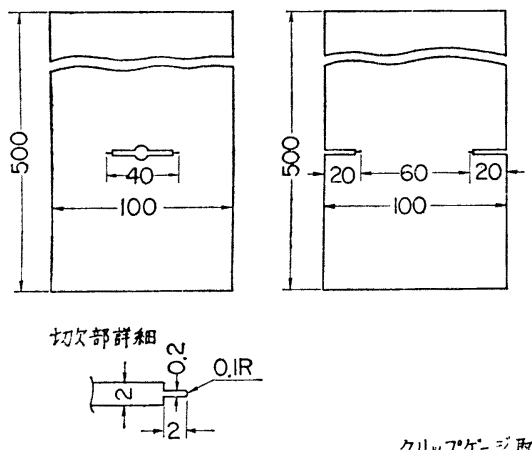

CODの部测法
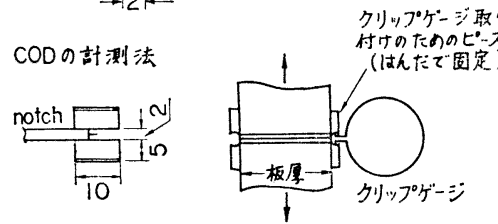

図 10 試験片形状㧍よび COD の詰測法

bに現われてくることがわかっ た。したがって全面降伏後に破 壞する場合には $\mathrm{CN}$ と $\mathrm{SN}$ の試 騟片でその破壞特性に差が現わ れる可能尘がある。

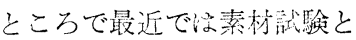
しての COD 倵験を小型の試験 片で行ならことの検討が行なわ れているが試験片が小型になれ

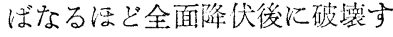
る可能性が多くなり，破壊特性が誠験片形状の影響を受け やすくなる。このため COD 試験等の菜材試験の試彩片選 択には十分の注意を払う必要がある。

このような観点から，ここでは小型の $\mathrm{CN}$ および $\mathrm{SN}$ 試

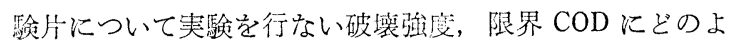
うな差が現われるかを調べた。

\section{1 供試材, 試験片形状および実験方法}

供試材は板厚 $27 \mathrm{~mm}$ の HT 80 である。化学成分叔よ び機械的性質を表 3 に示す。

試験片は板幅 $100 \mathrm{~mm}$, 切欠長さ $40 \mathrm{~mm}$ の試験片で C $\mathrm{N}$ タイプと SN タイプの 2 種類を制作した。切欠は機械加 工により, 先端半径 $0.1 \mathrm{~mm}$, 先端部 $2 \mathrm{~mm}$ ほ $0.2 \mathrm{~mm}$ 幅, 他は $2 \mathrm{~mm}$ 幅とした。COD の計測は切欠先端をはさむ位 置にピースをはんだづけし，その間にクリップゲージを挿 入して行なった。因 10 参照。

\section{2 実験結果および考察}

破壊強度に関する実験結果を示したのが図 11 で脑る。 一 $78^{\mathrm{C} C}$ 以上の実験では最高荷重を示したのち破断した。 最高荷重は CN の場合丸棒の引張強さと注洼等しく，SN の場合法それより約 1 制程度高い值を示した。この傾 向は全面降伏応力についてみられた $\mathrm{CN}$ と $\mathrm{SN}$ の美と同じである。 $-125^{\circ} \mathrm{C}$ の突騟ではほぼ最高荷重点で破断し

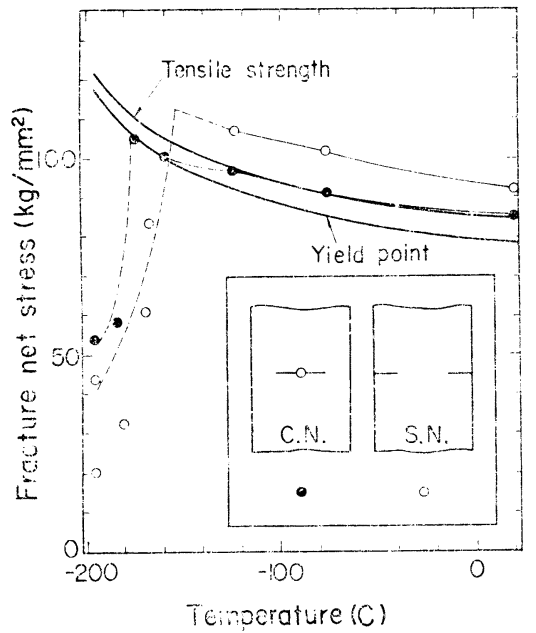

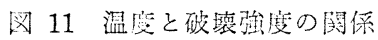

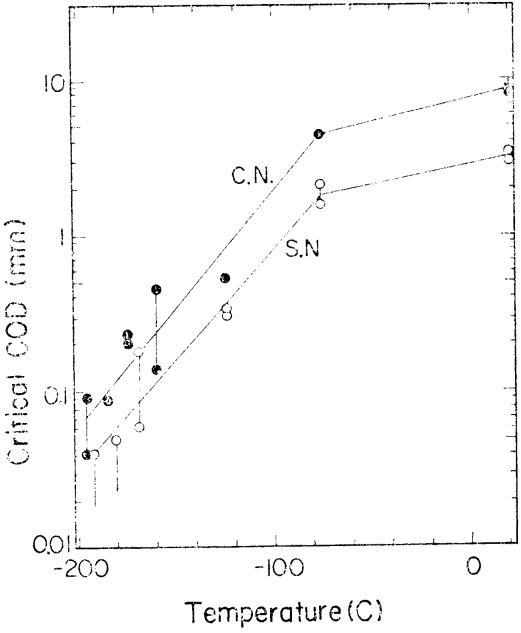

図 12 温度と限界 COD の関係 
た。破壊応力は高温域での結果と同じ傾向を示した。さらに低温域では破壊応力は逆にCN の場合が SN の場合 より高くなっている。この原因の1つとしては試験片に偏心荷重が作用したことがあげられるが, 図 12 の限界 COD の測定結果をみると， SN の限界 COD の大きい方でる CN の限界 COD より小さいことからすると，偏 心荷重の影響ばかりではないようである。限界 COD としては, 図 10 に示した方法により測定した值をそのま ま示してある。な拉，図 10 に示す方法により測定した COD は DM モデルで求めた切欠先端の值より大きめ の値が得られた。限界 COD は CN の場合が SN の場合より大きいようである。低温域では CN と SN との值 に差がないといら実験データも報告されているので断定的なことは言えないが，塑性变形量の大きい高温域では SN に比べて CN の場合に限界 COD が大きくなる。したがって破断時あるいは最高荷重時の COD の測定値を 限界 COD とするのであれば，SN の試験片を用いる方が安全側にあることになる。しかし実測の COD には延 性亀裂発生に上る变位が含まれる可能性がある（本実験では $-125^{\circ} \mathrm{C}$ 以上の実験で法破断洗立って延性亀裂の 発生が放らた）ので延性亀裂発生時の COD を限界 COD とするのが好ましいという考兄もある8。このため 今後法，延性亀裂発生時の COD が試験片形状の影響を受けるかどらかついても検討する必要がある。

\section{FEM 解析結果の相似性}

有限要素法 (FEM) で得られるのは数值解なので，その結果は定めた条件にしか適用できない。このため破壊 力学的考察を目的に FEM を利用する場合などでは数多くのケースについての計算が必要な場合もある。しかし これには多くの経費と学力を必要とする。この非能率的なことを少しでも解消するために，市る特定の条件のる とに得られた結果を他の条件に利用できないかといらことを調へておくことも意味の放ることであるう。弾性体 の解析では， ある特定の条件についての結果に簡単な比例計算を行ならだけで，寸法が比例的に変化したり，ヤ ング率が変化した場合の解析結果となることは容易にらなずける。ここでは弾塑性解を対象に，ある特定の条件 のもとに得られた結果を他の条件での解析結果とするにはどのような制約があるか調べてみた。弾塑性解析は增 分法とし，各增分間での計算は前段階の状態について平衡を考学る微小変形として以下に考察する。

\section{1 基礎関係式 9}

ある要素でのひずみ増分 $\{\dot{\varepsilon}\}$ と応力増分 $\{\dot{\sigma}\}$ の関係は次のように与えられる。

$$
\{\dot{\sigma}\}=[D]\left(\{\dot{\varepsilon}\}-\left\{\dot{\varepsilon}_{0}\right\}\right)
$$

ただし $\left\{\dot{\varepsilon}_{0}\right\}$ は固有ひずみ増分を表わしマトリックス $[D]$ は要素を構成している材料の性貿を表わす。 ひずみ増分 $\{\dot{\varepsilon}\}$ は節点の変位増分 $\{\dot{\delta}\}$ と次のような関係に西る。

$$
\{\dot{\varepsilon}\}=[B]\{\dot{\delta}\}
$$

ただし $[B]$ は節点の座標に関係したマトリックスである。

節点变位は構造物全体としての力の平衡条件より求まる。西る1つの要素について考光ると次式が成立する。

$$
\begin{aligned}
\{\dot{F}\} & =\int[B]^{T}[D][B] d v-\int[B]^{T}[D]\left\{\dot{\varepsilon}_{0}\right\} d v-\int[N]^{T}\{\dot{p}\} d v \\
& =[k]\{\dot{\delta}\}+\{\dot{F}\}_{\varepsilon_{0}}+\{\dot{F}\}_{P}
\end{aligned}
$$

ただし右辺第 1 項は要素の変形による節点力増分を, 第 2 項は固有ひずみによる節点力增分を, 第 3 項は物体

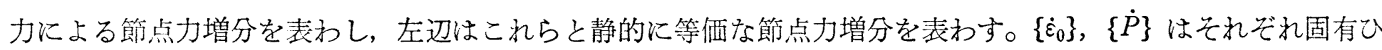

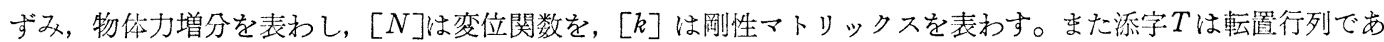
ることを示す。積分は要素内全体について行なら。

特定の節点についての平衡条件は要素からの節点力增分 $\{\dot{F}\}$ のうち節点 $i$ 亿関する力 $\left\{\dot{F}_{\imath}\right\}$ をすべての要素 について加光合わせ，これを外力增分 $\left\{R_{i}\right\}$ と等しいと置くことにより得られる。この操作をすへてての節点につ いて行なえば，変位增分 $\{\dot{\delta}\}$ を知数とする構造全体としての平衡条件式が得られ，これを解故ば節点変位增 分が求恋る。

\section{2 各マトリックスの性質}

ここでは, 三次元問題を考光, 要素は 4 面体とし要素内の応力, ひずみ, 物体力は一定とする。この場合, 変 位関数 $[N]$ は要素内の座標 $(x, y, z)$ の一次関数となり， $[B]$ は要素内で一定で, 節点が相対的な座標に関倸 する。ディメンジョンについてみると $[N]$ はノンディメンジョンであり， $[B]$ は $L^{-1}(L$ は距離を表わす）で ある。 
$[D]$ は，弾性域では $\left[D^{e}\right] を ，$ 塑性域では $\left[D^{P}\right]$ を使用する。 $[D]$ の成分を $d_{i j}(i, j=1 \sim 6)$ とすれば，弾 经域 $\left(\left[D^{e}\right]\right)$ で呮

となり，塑性域は，山田によれば10)

$$
d_{i j}=E \cdot f_{i j}(\nu) \quad(i, j=1 \sim 6)
$$

$$
d_{i j}=E \cdot f_{i j}(\nu)-\frac{4 G^{2}}{S_{o}} S_{i} \cdot S_{j}(i, j=1.6)
$$

となる。ただし

$$
\begin{array}{rlrl}
E & : \text { ヤング率 } & G: \text { 剪断㟠性率 }=E / 2(1+\nu) \\
\nu: \text { ポアッソン比 } & f_{i j}(\nu): \nu \text { の関数 } \\
S_{0}: \frac{9}{4} \bar{\sigma}^{2}(H+3 G) & H: \text { 加工硬化率 } \\
S_{i}, S_{j}: \text { 偏差応力成分 } & \bar{\sigma}: \text { 相当応力 }
\end{array}
$$

次に (3) 式関速して $[D],[B]$ は要素内で一定で苛るから

$$
\left.\begin{array}{l}
{[k]=\int[B]^{T}[D][B] d v=[B]^{T}[D][B] \cdot V} \\
\{\dot{F}\}_{\varepsilon_{0}}=\int[B]^{T}[D]\left\{\dot{\varepsilon}_{0}\right\} d v=[B]^{T}[D]\left\{\dot{\varepsilon}_{0}\right\} \cdot V
\end{array}\right\}
$$

となる。Vは要素の休頪を表わす。物体力の項では, 座標の原点を要素の重心にとると

$$
\begin{aligned}
& \iint_{V} \int_{V} x d x d y d z=\iiint_{V} y d x d y d z=\iiint_{V} z d x d y d z=0 \\
& \iiint_{V} d x d y d z=V
\end{aligned}
$$

なることを考慮すれば要素の任意の節点 $i$ につて

$$
\left\{\dot{F}_{i}\right\}=-\{\dot{P}\} V / 4
$$

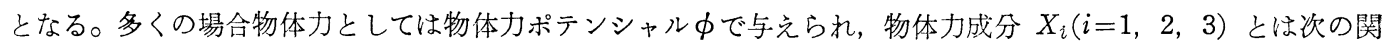
係汇ある。

$$
X_{i}=-\partial \phi / \partial x_{i} \quad(i=1,2,3)
$$

$\phi$ : 節点でのポテンシャル $\phi_{j}(j=1 \sim 4)$ により定められる。要素内の物体力を一定としているので， 内の座標の一次関数となる。したがって $(7)$ 式恃次のように書き改められる

$$
\left\{F_{x}\right\}_{P}=\frac{1}{24}[C]\left\{\phi^{e}\right\}
$$

$[C]$ は $L^{2}$ のディメンションをるつ。ただし， $\left\{\phi^{e}\right\}=\left(\left\{\phi_{1} \phi_{2} \phi_{3} \phi_{4}\right\}\right)^{T}$

\section{3 FEM 解析結果の相似性}

境界条件としての応力変位等の增加に対する弾性解析と弾 塑泩解析の相異は, 弾塑性解析では塑性域にある要素につい こ $\left[D^{P}\right] を$ 用いるということだけである。堌分法による弾塑 珄解の結果は各增分の和として与号られ, 初期状態は応力・ ひずみともに0であるから，2つの要素に执いて各堌分段階 での応力・ひずみ增分が同じで第れば，応力・ひずみ状態は 同じであり，要素の弹塑性快態も同じとなる。

2 つの解析対象物 $A, B$ を考光る。両者の寸法梳相似で离 门，要素分割も相似であるとし， $A$ と $B$ の材料の機械的性質 が翼なっているとする。機械的性筫に関係するのは $[D]$ 小

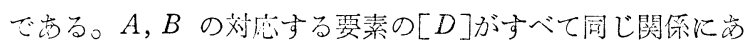

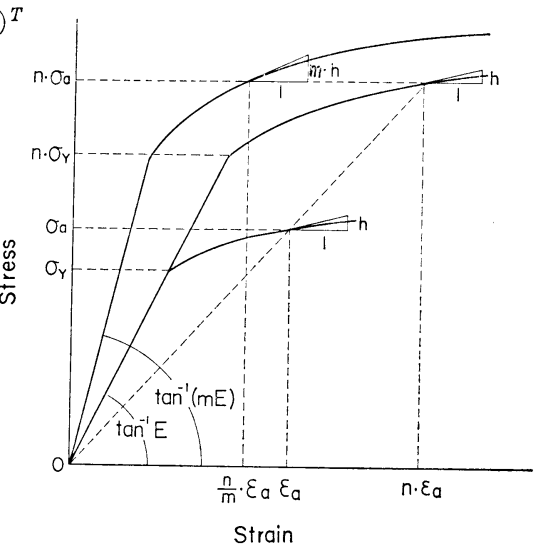

図 13 材料の機潋的性質変化比関する説明図

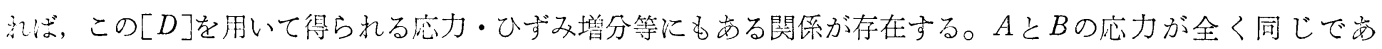

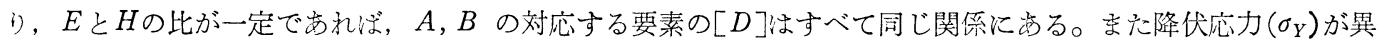
なっても降伏応力に対する応力の状態が同じで苛れば $[D]$ 注なんらその影锌を受けない。 
以上のようなことを考虑に入れて，Aに対する $B$ の寸法が $l$ 倍， $E$ 执よび $H か ゙ m$ 倍， $\sigma_{Y}$ が $n$ 倍（図 13）であ るとすれば, $A B$ の対応する要素のマトリックス間には次の関係が成立する。

$$
\begin{aligned}
& {[B]_{B}=\frac{1}{l}[B]_{A}} \\
& {[D]_{B}=m[D]_{A}} \\
& {[k]_{B}=\operatorname{lm}[k]_{A}} \\
& {[C]_{B}=l^{2}[C]_{A}}
\end{aligned}
$$

添字 $A, B$ はそれぞれ $A, B$ の要素のbのであることを示す。

ここで, $A$ に対する (3)式に $l^{2} \cdot n$ をかけた式について教える。左辺の各項は

$$
\begin{aligned}
& l^{2} \cdot n[k]_{A} \cdot\{\dot{\delta}\}_{A}=l \cdot m[k]_{A} \frac{l n}{m}\{\dot{\delta}\}_{A}=[k]_{B} \cdot\{\dot{\delta}\}_{B} \\
& l^{2} \cdot n\{\dot{F}\}_{\varepsilon_{0}}=\frac{1}{l}[B]_{A}{ }^{T} \cdot m[D]_{A} \cdot \frac{n}{m}\left\{\dot{\varepsilon}_{0}\right\}_{A} \cdot l^{3} V_{A}=[B]_{B} T \cdot[D]_{B} \cdot\left\{\dot{\varepsilon}_{0}\right\}_{B} \cdot V_{B} \\
& l^{2} \cdot n\{\dot{F}\}_{P}=l^{2}[C]_{A} \cdot n\left\{\phi^{e}\right\}_{A}=[C]_{B} \cdot\left\{\phi^{e}\right\}_{B}
\end{aligned}
$$

となる。

さらに，ひずみ增分を与克る(2)式については

$$
\{\dot{\varepsilon}\}_{B}=[B]_{B}\{\dot{\delta}\}_{B}=\frac{1}{l}[B]_{A} \cdot \frac{\ln }{m}\{\dot{\delta}\}_{A}=\frac{n}{m}\{\dot{\varepsilon}\}_{A}
$$

となり，応力增分を与兄る(1)式については

$$
\{\dot{\sigma}\}_{B}=[D]_{B}\left(\{\dot{\varepsilon}\}_{B}-\left\{\dot{\varepsilon}_{0}\right\}_{B}\right)=m[D]_{A} \cdot \frac{n}{m}\left(\{\dot{\varepsilon}\}_{A}-\left\{\dot{\varepsilon}_{0}\right\}_{A}\right)=n\{\dot{\sigma}\}_{A}
$$

となる。

したがって，Aについての(3)式の両辺に $l^{2} \cdot n$ をかけた式は, Bについての関係式となり外力は $l^{2} \cdot n$ 倍, 物 体力ポテンシャルは $n$ 倍, 変位は $\frac{l n}{m}$ 倍, ひずみは $\frac{n}{m}$ 倍, 応力は $n$ 倍となる。

な括， $[B]$ を前段階での変位増分を用いて修正するので等れば，変位は $\frac{n}{m}$ に関係するので $[B]$ は $\frac{n}{m}$ の影響を受

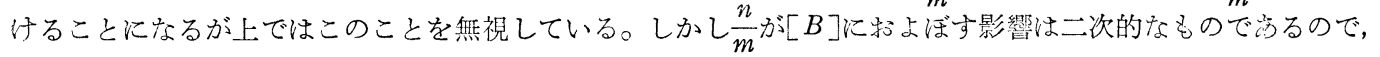

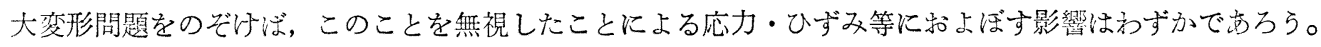

\section{5 結論}

1. 平面ひずみ括よび平面応力状態の場合について，FEM による弾塑性解析を行ない，センタノッチ技よび サイドノッチ試験片の変形挙動を比較した。その結果, 平面応力に比べて平面ひずみの場合に切欠近傍に高い応 力を生じること, 亀裂面方问の応力 $\sigma_{x}$ の影響に上り塑性域内の亀裂面に直角方向の応力 $\sigma_{y}$ はセンタノッチの 場合よりサイドノッチの場合に大きくなることがわかった。热た等ひずみ領域は平面応力の場合切欠面上の前方 へも広がるが，平面ひずみでは汪とんど広がらないことがわかった。

2. センタノッチ怙よびサイドノッチ試験片に応力筮料を塗布し引張試験を行ない, 塗料のはくりを観察する ことにより，同一負荷に対してセンタノッチ試験片の方がはくりが曊著であることがわかった。またすべりは， センタノッチ試験片では板厚和よび板幅方向に生じるが, サイドノッチでは主として板厚方向に生じることを確 認した。

3. センタノッチ怙よびサイドノッチの小形ディープノッチ試験を行ない，それぞれの試験片で限界值 COD 就よ゙破壞強度に差がある結果を得た。

4. FEM の各マトリックスの性質を調べることにより市る条件での解析結果から，寸法が比例的に変化した 場合, 材料の降伏点が变化した場合, 加工硬化率とヤング率とがその比を一定に保ちながら変化した場合なとの 弾塑性挙動を簡単に求められることを確缌し心。

本研究については，造船学会溶接研究委員会第 1 分科会主査金沢教授，第 2 分科会主查佐藤教授をはじめ委員 各位から有益なご討論と助言をいただいた。ここに深く謝意を表します。また本研究の機会を与えていただいた 
石川島播磨重工業(株)技術研究所藤田副所長，後藤部長，応力塗料実験につき便宜るはかっていただいた同所小 林研究員に感謝いたします。

\section{参考文 献}

1) T. Kanazawa, H. Mimura, S. Machida, T. Miyata, Y. Hagiwara : Some Critical Considerations on the Criteria for the Onset of Brittle Crack Propagation, Conference on Practical Application of Fracture Mechanics to Pressure-vessel Technology (May, 1971), Landon.

2) F. Koshiga: A Proposed Simple Theory of Overstressing Technique to Secure Pressure Vessels against Brittle Failure, ibid.

3) Y.Akita, T. Yada, K. Sakai, N. Iino : COD Approach for Evaluation of Brittle Fracture Initiation in Residual Stress Field, The First International Symposium of the Japan Welding Society-[3] (Nov., 1971), Tokyo.

4）金沢, 町田, 萩原：工菜的試験法としての曲げ COD 試験について, 日本造船学会論文集第 132 号(Dec., 1972).

5）佐藤，豊田，阪野，豊貞：塑性拘束が脆性破壞発生に打よぼす影響と軟質溶接継手の脆性破壊強度に関す る研究，日本造船学会論文集第 132 号 (Dec., 1972).

6）佐藤，豊田，小田：等長並列 line crack を有する材の変形挙動，日本造船学会溶接研究委員会第 1 分科 会資料 (1973), 1-245-73.

7）阪野：十字すみ肉溶接継手の強度ならびに切欠材の強度に関する研究，大阪大学溶接工学科卒業論文 (1970).

8）金沢，三波，宮，佐藤，征矢：静的 COD 拈よび動的 COD 飞関する一考察，日本造船学会論文集第 133 号(June, 1973).

9) Zienkiewicz, O.C., Cheung, Y.K.: マトリックス有限要素法, 培風館 (1970).

10) Yamada, Y., Kawai, T., Yoshimura, N., Sakurai, T.: Analysis of the Elastic Plastic Problems by the Matrix Displacement Method, Preprints of 2 nd Conf. on Matrix Method in Struct. Mech. (1968). 